DIW BERLIN

Discussion Papers

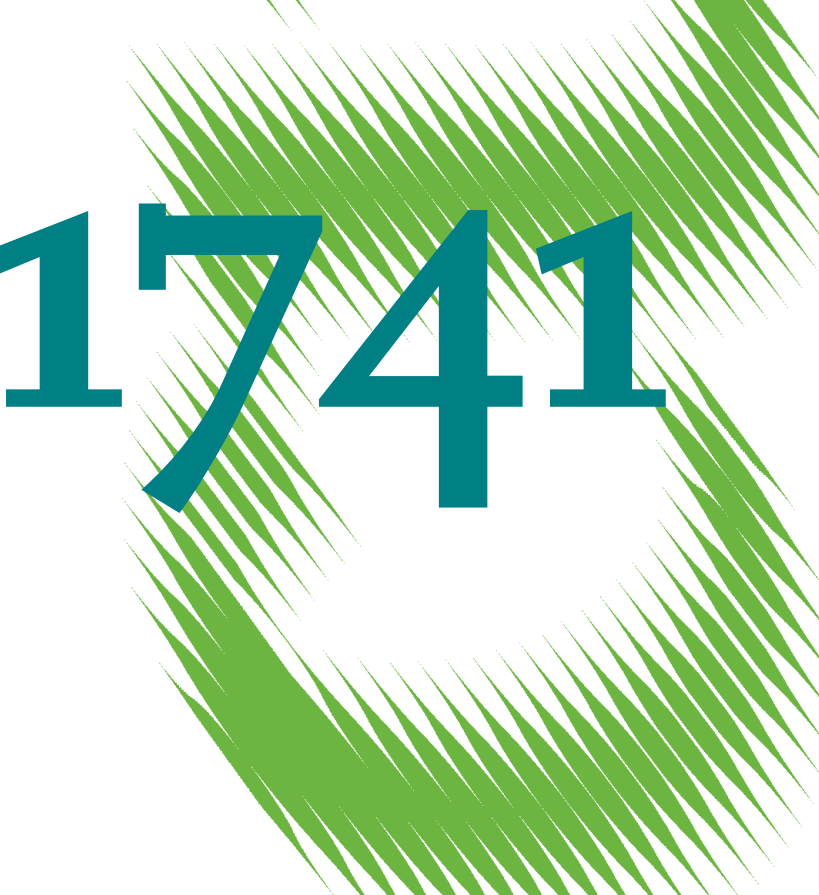

Labor Market and Distributional Effects of an Increase in the Retirement Age 
Opinions expressed in this paper are those of the author(s) and do not necessarily reflect views of the institute.

IMPRESSUM

(C) DIW Berlin, 2018

DIW Berlin

German Institute for Economic Research

Mohrenstr. 58

10117 Berlin

Tel. +49 (30) $89789-0$

Fax +49 (30) $89789-200$

http://www.diw.de

ISSN electronic edition 1619-4535

Papers can be downloaded free of charge from the DIW Berlin website:

http://www.diw.de/discussionpapers

Discussion Papers of DIW Berlin are indexed in RePEc and SSRN:

http://ideas.repec.org/s/diw/diwwpp.html

http://www.ssrn.com/link/DIW-Berlin-German-Inst-Econ-Res.html 


\title{
Labor Market and Distributional Effects of an Increase in the Retirement Age*
}

\author{
Johannes Geyerł Peter Haan‡ Anna Hammerschmid, and Michael Peters
}

June 14, 2018

\begin{abstract}
We evaluate the labor market and distributional effects of an increase in the early retirement age (ERA) from 60 to 63 for women. We use a regression discontinuity design which exploits the immediate increase in the ERA between women born in 1951 and 1952. The analysis is based on the German micro census which includes about 370,000 households per year. We focus on heterogeneous labor market effects on the individual and on the household level and we study the distributional implications using net household income. In this respect we extend the previous literature which mainly studied employment effects on the individual level. Our results show sizable labor market effects which strongly differ by subgroups. We document larger employment effects for women who cannot rely on other income on the household level, e.g. women with a low income partner. The distributional analysis shows on average no significant effects on female or household income. This result holds as well for heterogeneous groups: Even for the most vulnerable groups, such as single women, women without higher education, or low partner income, we do not find significant reductions in income. One reason for this result is program substitution.
\end{abstract}

Keywords: retirement age, pension reform, labor supply, early retirement, distributional effects, spillover effects, household.

JEL classification: J14; J18; J22; J26; H31.

\footnotetext{
${ }^{*}$ We thank the research data center of the Statistical Office Berlin-Brandenburg for data access and support. Moreover, we are grateful to participants of a seminar talk at the University of Würzburg, two LONGLIVES workshops, a DFG SPP 1764 workshop, the EALE 2017 conference, the annual conference 2017 of the German Economic Association, and the DIW GC Winter Workshop 2017. This study is funded by the German Federal Ministry of Education and Research (Bundesministerium für Bildung und Forschung, Förderlinie: "IKT 2020 - Forschung und Innovation", Förderkennzeichen: 16SV7585, Projekt LONGLIVES) within the JPI MYBL framework, by the DFG (Project HA5526/42) and SFB 190 - A02) and by the Forschungsnetzwerk fuer Altersicherung (FNA)

${ }^{\dagger}$ DIW Berlin, jgeyer@diw.de

${ }^{\ddagger}$ DIW Berlin, FU Berlin, Netspar, phaan@diw.de

${ }^{\S}$ DIW Berlin, BERA, ahammerschmid@diw.de
} 


\section{Introduction}

Aging populations challenge public pension systems. Therefore, since the 1990s, most OECD countries have reversed their retirement policies and started to encourage longer working lives, thus alleviating the decline of the working age population. Reforms include tighter qualifying conditions and increases in the early retirement age (ERA), the introduction of actuarial deductions for early retirement, increases in the normal retirement age (NRA), i.e. the age at which people can first draw full benefits without actuarial deductions 1 increases in the statutory retirement age (SRA), or a combination of these policies.

A large empirical literature analyzes labor market effects of various pension reforms $\stackrel{2}{2}^{2}$ Most of these studies use administrative social security data and exploit the quasiexperimental variation induced by pension reforms to estimate causal labor market effects. Administrative data have the advantage of providing accurate information about the working and earnings history of large samples or even the entire population. Yet, in general, social security data primarily include individual information and, therefore, it is not possible to study effects of pension reforms on the household level. Consequently, with individual data it is not possible to analyze spill-over effects of pension reforms on spousal employment, i.e. the added worker effect, and to focus on heterogeneous effects of the pension reform by household composition, spousal employment, or by household income. Moreover based on individual data, distributional analyses of pension reforms are only partially informative since other sources of income on the household level, most importantly the spousal income, cannot be considered. However, in order to evaluate the employment effects and, in particular, the distributional consequences of pension reforms, it is important to consider the heterogeneity along the household dimensions. More specifically, when designing and reforming the pension system it is important to understand which groups respond to pension reforms and how household net income across the income distribution and for specific vulnerable groups - is affected.

Therefore, in this paper, we focus, in addition to the individual level on the household level, and quantify potential spill-over effects on spousal employment, heterogeneous employment effects and distributional consequences induced by an increase in the ERA. For identification of these effects, we follow Geyer and Welteke (2017) and exploit the

\footnotetext{
${ }^{1}$ This definition of the NRA is equal to the OECD definition of the "pensionable age".

${ }^{2}$ Examples are Krueger and Pischke (1992); Duggan, Singleton, and Song (2007); Mastrobuoni (2009); Coe and Haverstick (2010); Hanel and Riphahn (2012); Staubli and Zweimüller (2013); Vestad (2013); Atalay and Barrett (2015); Brinch, Vestad, and Zweimüller (2015); Lalive and Staubli (2015); Hernæs, Markussen, Piggott, and Røed (2016); Manoli and Weber (2016); Oguzoglu, Polidano, and Vu (2016); Engels, Geyer, and Haan (2017); Geyer and Welteke (2017).
} 
exogenous variation of the 1999 pension reform in Germany, which abolished the old-age pension for women. This reform meant that women born in 1951 could still go into early retirement at age 60, while women born in 1952 would not be able to retire early until 63. The reform is especially interesting due to its intensity (three year increase) and immediateness (direct cutoff and no monthly lags). The arbitrary assignment around the cutoff allows to credibly identify causal effects using a Regression Discontinuity Design (RDD). In contrast to Geyer and Welteke (2017), we do not make use of the individual administrative data from the German pension insurance. Instead we use repeated cross sections from the German micro census, which every year provides information for $1 \%$ of all German households (about 370,000 households). Thus, this data allows for going beyond the analysis on the individual level and to also focus on the effects of the pension reform on the household level. Crucially, the micro census includes enough observations to apply a credible identification strategy, even for subgroups.

In the first part of the empirical analysis, we use a RDD to evaluate the labor market effects for women and spill-over effects on spousal employment. We concentrate on several different outcome variables, namely employment, retirement, unemployment, and nonemployment. We quantify the average employment effect for the full population and focus on different subsamples to investigate effect heterogeneity of the pension reform on the individual and household levels. In particular, we study the effects by education, household composition, as well as by the employment status and spousal earnings. In the second part, we use the same empirical design and analyze the distributional implications of the pension reform for the different subgroups. We estimate the effect of the reform on female income and on net household income.

In addition to the mentioned literature on the employment effects of pension reforms, our paper is related to studies that focus on retirement behavior in the household context. For example Blau (1998); Gustman and Steinmeier (2000); Michaud and Vermeulen (2011) estimate structural retirement models and show that complementarities in spouses' leisure are a likely explanation for joint retirement behavior. Other studies use exogenous variation in pension age rules or incentives to identify joint retirement behavior in couples (e.g. Banks, Blundell, and Casanova, 2010; Stancanelli and van Soest, 2012; Atalay and Barrett, 2016; Lalive and Parrotta, 2017; Selin, 2017). The findings of this literature are mixed, yet most studies find larger spill over effects for women than for men. As mentioned above, in general household information is missing in administrative data sets which are used for the analysis of pension reforms. At the same time household surveys often have too few observations for credible identification of causal effects. Therefore, only few studies focus on heterogeneous employment effects of pension reforms on the 
household level. One notable exemption is Cribb, Emmerson, and Tetlow (2016). They focus on the gradual increase in the ERA over several cohorts for women in the UK using the labor force survey. They find no significant differences by marital status, age of the partner, or housing wealth. Finally, our study is linked to the growing literature which quantifies how economic shocks, such as unemployment or disability, can be reduced or partially insured in the household context, see e.g. Blundell, Pistaferri, and SaportaEksten (2016), Autor, Kostøl, and Mogstad (2015) or Haan and Prowse (2015).

The clean identification strategy exploiting the immediate increase in the ERA from age 60 to 63 between two adjacent cohorts in combination with the large and rich household data from the micro census allow us to extend the previous literature. In line with Geyer and Welteke (2017), we find that raising the ERA leads on average to a sharp reduction in retirement, to positive employment effects, and to an increase in unemployment and inactivity. In addition, our study provides several novel results on the individual and household levels. First, we do not find significant spillover effects of the reform on male employment behavior. This is consistent with previous studies that document sizable and significant spillover or added work effects for women but not for men, see e.g. Lalive and Parrotta (2017). Second, we document important heterogeneity of labor market effects. At the individual level, we find both highly educated women and single women to have larger employment effects. Importantly, we also document remarkable heterogeneity with respect to household characteristics. Women with retired or low income partners have the largest employment effects. These heterogeneous results can be explained by better labor market perspectives and working conditions or by different labor market attachment for highly educated women. Moreover, the income effect on the household level, provided by the partners' income, is an important factor explaining the women's reaction to the reform. Finally, our distributional analysis shows that on average there are no significant effects of the reform on individual or household income. This results holds as well for heterogenous groups: Even for the most vulnerable groups, such as single households, women without high education, or low partner income, we do not find significant reductions in income. One reason for this result is program substitution. For women without high education we find a significant effect of the increase in the ERA on transfer receipt.

The paper is organized as follows. Section 2 provides an overview about the institutional context of the German public pension system and describes details of the 1999 pension reform. In the following section, we describe the data and show descriptive statistics of the estimation sample. Section 4 explains the empirical methods and assumptions we use to identify the causal effect of an increase in the retirement age. Sections 5 and 6 
show the findings of our empirical analysis of labor market outcomes and income. Finally, Section 7 concludes.

\section{Institutional background}

\subsection{The German public pension system}

The statutory public pension system covers most private and public sector employees 3 and provides old-age pensions, disability pensions, and survivors benefits. The system is financed by a pay-as-you-go (PAYG) scheme and has a strong contributory link: pension benefits depend on the entire working history. In principle, old-age pensions are proportional to lifetime labor earnings. Entitlements can also be acquired during periods of unemployment, for child raising, and for informal care provision.

For the cohorts we consider in this study, women born in 1951 and 1952, there exist four pathways into early retirement, i.e. claiming retirement benefits before reaching the NRA: (1) the pension for women; (2) the invalidity pension; (3) the pension after unemployment or after old-age part-time work; and (4) the pension for the long-term insured.

The first two of these pathways, the pension for women and the invalidity pension, allow drawing benefits starting from 60 years of age 4 The other two early retirement programs allow retirement starting from age 63. The pension for the long-term insured enables individuals with particularly long insurance records of at least 35 years to retire early. The calculation of pension benefits does not differ across these pathways, however early retirement is associated with deductions of $0.3 \%$ per month before the NRA. Table 1 summarizes the changes in retirement and labor market rules.

\footnotetext{
${ }^{3}$ The public pension system covers more than $80 \%$ of the workforce with the exceptions of groups that are not subject to compulsory insurance: civil servants, most self-employed, and low income workers ("geringfügige Beschäftigung").

${ }^{4}$ Individuals who are not able to work due to severe health conditions can retire before the age of 60 through the disability pension program. Note that the German pension system provides two different types of pensions due to impaired health. The disability pension ("Erwerbsminderungsrente") is similar to disability benefits in the US. Eligibility for full benefits requires that an individual is unable to work more than 3 hours a day for at least six months. Eligibility for partial disability benefits require that the individual is unable to work more than 6 hours a day. In addition, eligibility requires 5 years of contributions. It is the only pension that is available prior to turning 60 . When reaching the NRA the disability pension is converted into an old-age pension of the same amount. In addition, there is the aforementioned invalidity pension ("Rente wegen Schwerbehinderung") that is available from age 60 for people with a severe disability status under German law. Eligibility requires a degree of disability of $50 \%$ or more and does not require work incapacity. The ERA of this pension has been increased since 2012 .
} 
Table 1: Changes in retirement labor market rules by cohort

\begin{tabular}{|c|c|c|}
\hline \multirow[t]{2}{*}{ Labor market status } & \multicolumn{2}{|c|}{ Differences in rules by birth cohort } \\
\hline & 1951 & 1952 \\
\hline \multicolumn{3}{|l|}{ Retirement } \\
\hline Pension for women & $\begin{array}{l}\text { The ERA for women fulfilling el- } \\
\text { igibility criteria is } 60 \text { (with per- } \\
\text { manent deductions; } 0.3 \% \text { per } \\
\text { month retiring before the NRA } \\
\text { of } 65 \text { ). Maximal deductions } \\
\text { amount to } 18 \% \text {. }\end{array}$ & abolished \\
\hline Invalidity pension & $\begin{array}{l}\text { The ERA for women fulfilling el- } \\
\text { igibility criteria is } 60 \text { (with per- } \\
\text { manent deductions; } 0.3 \% \text { per } \\
\text { month retiring before the NRA } \\
\text { of } 63 \text { ). Maximal deductions } \\
\text { amount to } 10.8 \% \text {. }\end{array}$ & $\begin{array}{l}\text { ERA and NRA increase simul- } \\
\text { taneously by one month per } \\
\text { month-of-birth cohort for women } \\
\text { born between January and June } \\
1952 \text {. ERA and NRA remain } \\
\text { constant at } 60+6 \text { months and } \\
63+6 \text { months for women born } \\
\text { between July and December. }\end{array}$ \\
\hline Disability pension & \multicolumn{2}{|c|}{ no change } \\
\hline \multicolumn{3}{|l|}{ Unemployment benefits } \\
\hline$A L G I$ (short-terms benefits) & \multicolumn{2}{|c|}{ no change } \\
\hline$A L G I I$ (long-term benefits) & \multicolumn{2}{|c|}{ no change } \\
\hline Inactivity & \multicolumn{2}{|c|}{ no change } \\
\hline Employment & \multicolumn{2}{|c|}{ no change } \\
\hline
\end{tabular}

\subsection{The 1999 pension reform}

The 1999 reform abolished the pension for women for cohorts born after 1951. Effectively, the reform raised the ERA for most women to at least 635 Women born before 1952 could claim the pension for women if they fulfilled certain qualifying conditions. The eligibility criteria were: (i) at least 15 years of pension insurance contributions; and (ii) at least 10 years of pension insurance contributions after the age of 40 . These criteria ensured a minimum labor market attachment of eligible women. According to Geyer and Welteke (2017), about $60 \%$ of all women born in 1951 were eligible for the old-age pension for women. Due to the reform, women born in 1952 lose an important option

\footnotetext{
${ }^{5}$ The pension after unemployment or after old-age part-time work was abolished at the same time as the pension for women. However, this does not affect our analysis, as the ERA for this pension type was already 63 .
} 
to exit the labor market before age $635^{6}$ At age 63 , people with a long insurance record can retire with deductions. As explained above, the only remaining retirement pathway before age 63 is the invalidity pension. The ERA (60) and the NRA (63) of the invalidity pension was increased by one month per month-of-birth cohort for women born between January and June 1952; for women born between July and December 1952 ERA and NRA for the invalidity pension were $60+6$ months and $63+6$ months, respectively.[JO According to the data of the (Deutsche Rentenversicherung, 2017) the claiming behavior for the invalidity pension in the years under study did not change: Between 2010 and 2014 about 7 to $8 \%$ of all new female retirees used this pathway. This is not surprising since even before the 1999 reform, if women had the choice between the invalidity pension or the pension for women, the former was more attractive because of a lower NRA and lower deductions.

As a results of these pension reforms, the remaining options for women born after 1951 to exit the labor market before age 63, are unemployment benefits, disability pensions, or inactivity. Geyer and Welteke (2017) discuss in detail the potential employment and substitution effects of an increase in the ERA. First, given the strong interdependence between unemployment benefits and pensions in Germany, see e.g. Engels, Geyer, and Haan (2017), an increase in the ERA is likely to affect the take-up of unemployment benefits in two ways: individuals have an increased incentive to postpone entry into unemployment. This would lead to a shift in increased unemployment entry from 58 (cohort 1951) to 61 (cohort 1952) years, i.e. 24 months before reaching the cohort-specific ERA, since the maximum entitlement for unemployment is two years. In addition, unemployment rates among 60 to 63 year-old women may increase due to program substitution because of the abolishment of the early retirement option, i.e. women who want to exit employment between the old and new ERA must take another path to exit the labor market. Second, substitution into the disability pension, the only pathway to retirement before reaching the ERA, could be possible. However, in Germany, health-related eligibility criteria for disability pensions are relatively strict, especially since a reform in 2001:7 Therefore, using disability pensions as a pathway to a regular old-age pension is difficult and not typically an attractive option. Moreover, since 2001, actuarial deductions also apply to this type of pension. The pension is permanently reduced by $0.3 \%$ per month if retiring before the NRA. Third, women who are neither eligible for disability pension nor unemployment benefits may choose inactivity, i.e. exit the labor force without benefit receipt.

\footnotetext{
${ }^{6}$ In 2011 about $40 \%$ of all new female retirees used the pathway pension for women (Deutsche Rentenversicherung, 2017).

${ }^{\top}$ About $40 \%$ of all applications are rejected.
} 


\section{Data}

\subsection{Data Source}

For our analysis, we use the German micro census, which is a representative annual survey with roughly 370,000 German households and 830,000 persons per year, corresponding to a $1 \%$ sample of the German population 8 To cover the most relevant period for the cohorts around the introduction of the 1999 pension reform, we use repeated cross sectional micro censuses for the years 2011 - 2015. Over this period, we can observe the labor market status and retirement of women born in 1951 and 1952 for the ages 60 to 62.

The micro census is well suited for our analysis. First, the sample size is large, in particular compared to other survey-based data sets that can be used to study the effect of pension reforms at the household level. The large number of observations allows us to restrict the sample to cohorts around the cutoff of the reform. Thus, treatment and control groups are very homogeneous, i.e. their birth dates differ only by one year. This is important for a convincing identification strategy of the treatment effect. Moreover, with such a large sample size it is possible to robustly identify the effects for heterogeneous subsamples, which is the central focus of our analysis. Second, the micro census includes rich information about all household members, including marital status, household income, as well as individual information about employment, education, and income of all household members. As mentioned above, this information is usually not available in administrative data which have been previously used to estimate the employment effects of pension reforms on the individual level, e.g. Geyer and Welteke (2017).

The micro census does not include information about the working history. Therefore, we cannot observe whether an individual fulfills the eligibility criteria for drawing early retirement benefits (the pension for women requires at least 15 years of employment and at least 10 of those after the age of 40). Thus, instead of estimating the average treatment effect (ATE) of the reform, we estimate the intent to treat effect (ITT) 9

\footnotetext{
${ }^{8}$ The survey started in 1957 and contains a broad range of individual and household information, including detailed socioeconomic characteristics. The data are available as repeated cross-sections and were accessed in the research data center of the Statistical Office Berlin-Brandenburg. The micro census is part of the official statistics in Germany and selected individuals are legally required to participate. For more information about the data, see e.g. Destatis (2018) and FDZ der Statistischen Ämter des Bundes und der Länder (2017).

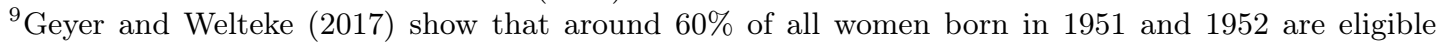
for the specific pathway into retirement. Further, comparing the ITT and the ATE, they show that scaling the ITT estimates with this fraction is very close to the ATE.
} 


\subsection{Sample Selection and Summary Statistics}

Table 2 provides descriptive evidence about the outcome variables and the main individual and household characteristics for the estimation sample of women aged 60-62 born in 1951 and 1952 10 In the first panel, we focus on the labor market outcomes. We distinguish between four labor market states: retirement, employment, unemployment, and inactivity. We define an individual as retired if she receives pension benefits from the German pension insurance. The category employment consists of individuals in paid work who do not receive pension benefits. Unemployment includes all individuals who are neither employed nor retired and receive out of work transfers ${ }^{11}$ and the remaining non-employed and non-retired individuals are classified as inactive. The shares in the different employment states strongly vary between the two cohorts. This is first evidence for a strong effect of the pension reform. More specifically, about $36 \%$ of all women aged 60-62 born in 1951 are classified as retired. For women born from 1952, the pension reform closes the most important pathway to retirement before the age of 63 . Therefore, the share is reduced to about $18 \%$ of all women; these women receive disability or invalidity pensions, which are the only pathways to retirement before the age of 63 for women born after 1951, see Table 1. In contrast, the share of employment, unemployment, and inactivity is higher among the women born in 1952. Employment rates of women born in 1952 are about 10 percentage points higher, the share in unemployment increases by almost 2 percentage points and inactivity increases by about 6 percentage points.

In the second part of Table 2 we present income information that is the outcome for the distributional analysis. The micro census includes information about individual and household net income ${ }^{12}$ The data show that despite the sizable differences in the employment states, both the individual and the household income, are similar for women from the two cohorts.

In the two last panels, we present individual and household specific characteristics for the two cohorts. As expected, age, educational outcomes, the share in couple households ${ }^{13}$, the share of women in West Germany, as well as household specific variables

\footnotetext{
${ }^{10}$ We exclude civil servants and self employed women because they are, in most cases, exempt from the mandatory public pension insurance.

${ }^{11}$ Out of work transfers comprise unemployment benefits (ALG) and means-tested welfare benefits (ALG II/social benefits, according to Hartz IV).

${ }^{12}$ Income variables are only recorded in brackets in the micro census. To generate approximate continuous variables, we assume that everyone in the respective income bracket receives the mean of the respective lower and upper bound of the income bracket. This procedure is used analogously for all income measures (household, individual, partner income). The income measure includes all sources of income including transfers net of taxes.

${ }^{13}$ Couple households include married and non-married couples. In the micro census, couples can only be linked if they actually share a household and live together. Thus, we do not capture couples who
} 
such as the partner's income and employment state or the age difference between the spouses are very similar for women born in 1951 and 1952. This similarity is important for the identification strategy proposed in the following section. Finally, note that for each cohort, we observe over 11,000 women, thus the main specification in the empirical analysis is based on more than 22,000 observations.

Table 2: Summary statistics by cohort

\begin{tabular}{|c|c|c|}
\hline Cohort & 1951 & 1952 \\
\hline \multicolumn{3}{|l|}{ Labor market status } \\
\hline Retired & .357 & .183 \\
\hline Employed & .418 & .516 \\
\hline Unemployed & .060 & .076 \\
\hline Inactive & .165 & .225 \\
\hline \multicolumn{3}{|l|}{ Income information } \\
\hline Own income (per Month in Euro) & 933 & 947 \\
\hline Household income (per Month in Euro) & 2,365 & 2,470 \\
\hline \multicolumn{3}{|l|}{ Individual characteristics } \\
\hline Age & 61 & 61 \\
\hline High education & .159 & .151 \\
\hline Couple & .702 & .706 \\
\hline West & .785 & .794 \\
\hline Children & .123 & .124 \\
\hline \multicolumn{3}{|l|}{ Partner characteristics } \\
\hline Partner income & 1,788 & 1,894 \\
\hline Age gap & -2.726 & -2.753 \\
\hline Partner retired & .551 & .536 \\
\hline Partner employed & .341 & .358 \\
\hline Partner unemployed & .036 & .037 \\
\hline Partner inactive & .073 & .069 \\
\hline Number of observations & 11,192 & 11,315 \\
\hline Number of observations partners & 7,852 & 7,989 \\
\hline \multicolumn{3}{|c|}{$\begin{array}{l}\text { Source: RDC of the Federal Statistical Office and Statistical Offices of the Länder, } \\
\text { Mikrozensus, } 2011-2015 \text {, own calculations. } \\
\text { Descriptive statistics are shown for the estimation sample of } 60-62 \text { year old women. } \\
\text { Retired = receiving retirement benefits from German Pension Insurance. Employed } \\
=\text { in employment, not retired. Non-employed = neither retired, nor employed. Un- } \\
\text { employed = non-employed, with ALG /ALGII. Inactive = non-employed, without } \\
\text { ALG/ALGII. Education classification based on ISCED (low: ISCED } 1^{*} \text { and } 2^{*} \text {, } \\
\text { medium: ISCED } 3^{*} \text { and } 4^{*} \text {, high: ISCED } 5^{*} \text { and higher). Age gap: female - male age } \\
\text { in couple. Income values have been imputed from categorical variables. Children: } \\
\text { Indicator for non-married children living in household. }\end{array}$} \\
\hline
\end{tabular}

\section{Empirical strategy}

For the estimation of the labor market effects of the increase in the ERA and the distributional analysis, we follow Geyer and Welteke (2017) and exploit the variation induced

live in separate places, which is a very small share of all couples. 
by the 1999 pension reform in a regression discontinuity design 14 The research design is implemented by the following empirical model:

$$
y_{i}=\alpha+\beta D_{i}+\gamma_{0} f\left(z_{i}-c\right)+\gamma_{1} D_{i} f\left(z_{i}-c\right)+X_{i}^{\prime} \delta+\epsilon_{i},
$$

where $\beta$ captures the effect of the pension reform and indicator $D_{i}=1$, if the individual was born on or after January 1, 1952. The month of birth $z_{i}$ enters the empirical model in difference to the reform cutoff $c$, which is January 1952. In our baseline specifications, we include a linear trend in the running variable, $f\left(z_{i}-c\right)=z_{i}-c$. The specification allows for different slopes before and after the cutoff. In a robustness check, we replicate the results using a quadratic trend in the running variable. Additional control variables (summarized in $X_{i}$ ) include partnership status, number of children, educational information, information about region, nationality, and age effects. For couples, we also include the age gap between partners 15

In the empirical analyses, we focus on different outcome variables $y_{i}$. We concentrate on retirement, employment, unemployment, and inactivity of women to describe the labor market effects. In addition, we analyze potential spillover effects for the spouse, estimating the effect on employment and retirement of men in a couple with a woman born in years 1951 or 1952 . For the distributional analysis, we study the effect on individual and household net income. The central aim of this study is to understand the heterogeneous effects of the pension reform by individual and household characteristics. Therefore, in addition to estimations using the full sample, we conduct separate analyses for sub-groups defined by central individual and household characteristics.

\section{Results - labor market effects}

This section presents the results of our empirical analysis of labor market outcomes. In the first part, we focus on the average labor market effects of the pension reform. Then, we analyze potential spillover effects of the pension reforms on the labor market outcomes of male partners. Finally, we investigate heterogeneous patterns of the labor

\footnotetext{
${ }^{14}$ Geyer and Welteke (2017) provide detailed evidence that the identifying assumptions for this research design are fulfilled. First, it is impossible to manipulate the treatment assignment variable, which is the month of birth. Second, Geyer and Welteke (2017) show that other policy changes cannot explain differences between the 1951 and 1952 cohorts. Third, as documented in Table 2 the observable characteristics of women born in the two adjacent cohorts are very similar.

${ }^{15}$ We do not include the partner's retirement status or partner's income as they might be potentially endogenous because of spillover effects. In a robustness check (not reported), we included these variables which did not affect the results of the central outcome. This is consistent with our results of no significant spillover effects discussed in Table 5
} 
market effects across different sub-samples. This allows us not just to shed light on potentially differential individual reactions to the reform by important individual and household characteristics, but also to better understand the mechanisms driving the labor market effects.

\subsection{Average effects}

\subsubsection{Graphical analysis}

We begin with a graphical analysis of the average labor market effects. Figure 1 shows the average share in retirement, employment, unemployment, and inactivity by birth months 24 month before and after the cut-off (January, 1st, 1952) ${ }^{16}$ The retirement rate drops sharply from nearly $40 \%$ to around $20 \%$ at the first birth month (January 1952) that is affected by the pension reform 17 Roughly half of this 20 percentage point drop in retirement is reflected in a sharp increase in the employment rate post-reform. The remaining half of the drop in retirement increases unemployment and inactivity. As the lower panel of Figure 1 shows, the effect on inactivity exceeds the small increase in unemployment in the affected cohorts.

The cohort trends on both sides of the reform cutoff show that women born in later cohorts are more strongly attached to the labor market. The employment rate before and after the cutoff increases by roughly 10 percentage points from the oldest to the youngest cohorts in the respective two-birth year window. Similarly, retirement and inactivity are overall downward sloping. In the estimation analysis based on the RDD, we control for these cohort trends in the labor market.

\footnotetext{
${ }^{16}$ Note that the graphical analysis includes observations of women born two years around the cutoff to display the overall trend in labor market outcomes on both sides of the discontinuity. The main regression analysis only includes observations of women born in 1951 and in 1952 in order to keep the treated and control groups as similar as possible

${ }^{17}$ As mentioned above, the group of retirees not only consists of regular old age pensioners, but also includes invalidity pensioners and old age pensioners in disability pensions. These retirement schemes are available before the age of 63 . Therefore, the post-reform retirement rate does not drop to zero at the reform cutoff.
} 
Figure 1: Graphical analysis: labor market status 24 months before and after the cut-off

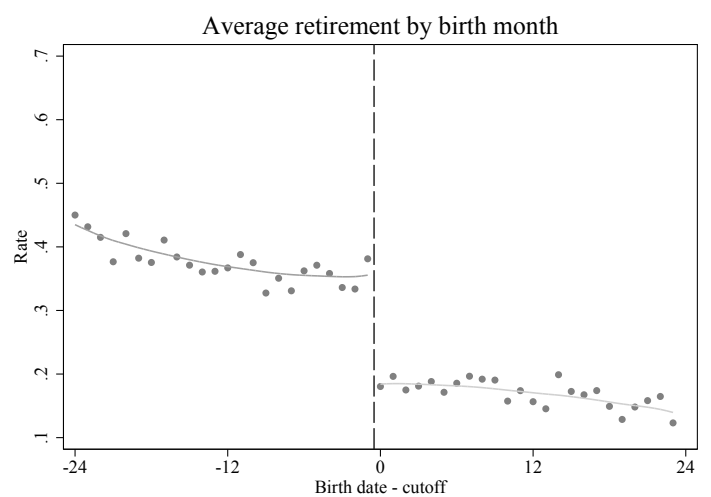

Average retirement

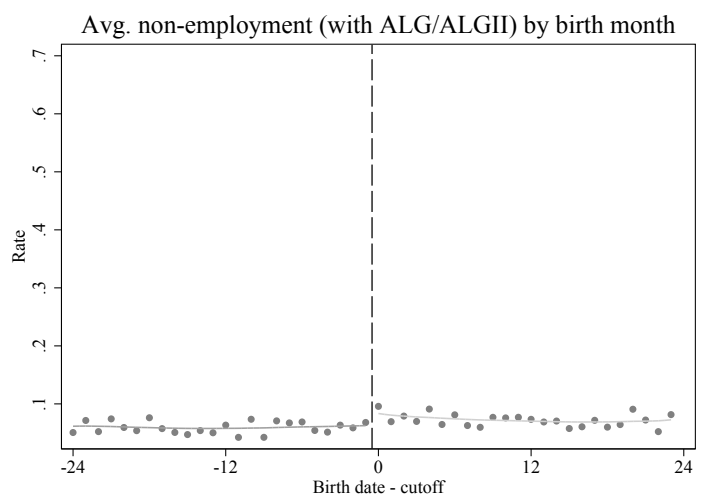

Average non-employment with benefits

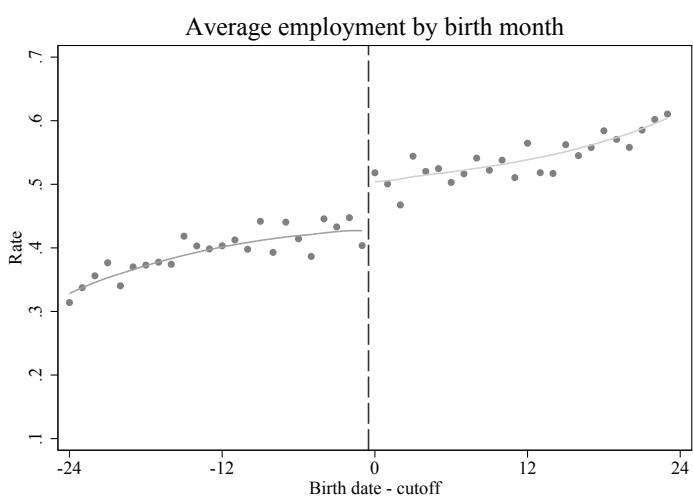

Average employment

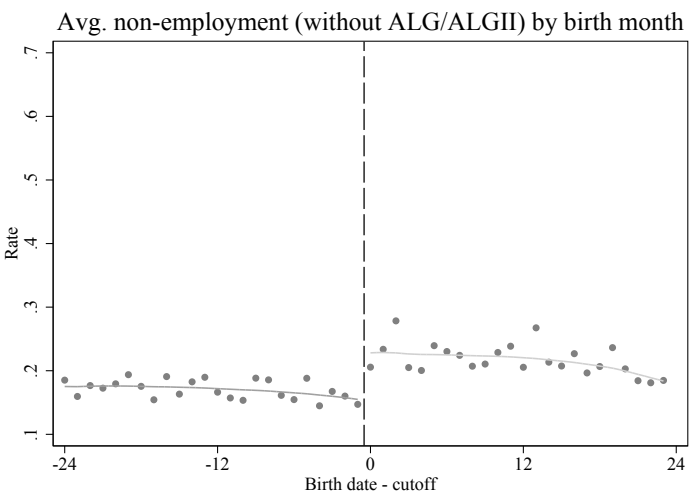

Average non-employment without benefits

Source: RDC of the Federal Statistical Office and Statistical Offices of the Länder, Mikrozensus, 2011-2015, own calculations. 


\subsubsection{Regression results}

We now turn to the estimation results of the ITT effect using the RDD (see Equation 1). The main results are displayed in Table 3 . We show the results for the four labor market outcomes in two different specifications. Specification I only includes the treatment indicator and a linear trend in the running variable that is allowed to differ on both sides of the cut-off. In addition, Specification II controls for individual and household characteristics.

Our results confirm the findings in Geyer and Welteke (2017): the pension reform has a sizable effect on labor market outcomes. On average, the effect on retirement for women aged 60-62 amounts to about 16 percentage points, which is an increase of close to $50 \%$ relative to the pre policy mean of $36 \%$. This point estimate is highly significant and does not substantially change after controlling for individual and household characteristics. Our results imply that the pension reform leads to a positive average employment effect of about 8.4 percentage points. The effect is slightly smaller (7.5 percentage points) in the base specification without control variables. In the last four columns of Table 3 we turn to the effect on unemployment and inactivity. We find positive effects for both labor market states; the effect on inactivity (6 percentage points) is larger than the effect on unemployment (2 percentage points). The effects on unemployment and inactivity only increase slightly if we drop the additional control variables.

The estimated linear trends before and after January 1952 are insignificant. This is not surprising since we use a homogeneous sample of women, born in two adjacent years. When we increase the window and include women born in cohorts 1950 - 1953 (see Table A.2 in Appendix) the time trends are significant for retirement and employment, which is in line with the graphical analysis (Figure 1). The estimated coefficients of the remaining control variables are in line with expectations. For instance, single women and women with higher education have higher employment rates. Further, employment rates decrease with age. Finally, we find sizable differences between women in East and West Germany. Most important retirement rates are markedly higher in the East since East German women, on average, have longer employment histories and are more likely to be entitled to the women's pension.

\section{Robustness Check for average labor market effects}

In the Appendix, we present results of additional regressions using quadratic or cubic time trends (Table A.1) and including women born in cohorts 1950 - 1953 (Table A.2). Overall, the point estimates of the treatment variable only slightly differ from the results 
Table 3: Treatment effects main specification

\begin{tabular}{|c|c|c|c|c|c|c|c|c|}
\hline & \multicolumn{2}{|c|}{ Employed } & \multicolumn{2}{|c|}{ Retired } & \multicolumn{2}{|c|}{ Unemployed } & \multicolumn{2}{|c|}{ Inactive } \\
\hline & I & II & I & II & I & II & I & II \\
\hline Treatment & $\begin{array}{c}0.0748^{* * *} \\
(0.0184)\end{array}$ & $\begin{array}{c}0.0839^{* * *} \\
(0.0187)\end{array}$ & $\begin{array}{c}-0.1634^{* * *} \\
(0.0141)\end{array}$ & $\begin{array}{c}-0.1608^{* * *} \\
(0.0148)\end{array}$ & $\begin{array}{c}0.0184^{* *} \\
(0.0074)\end{array}$ & $\begin{array}{c}0.0170^{* *} \\
(0.0071)\end{array}$ & $\begin{array}{c}0.0703^{* * *} \\
(0.0173)\end{array}$ & $\begin{array}{c}0.0599^{* * *} \\
(0.0163)\end{array}$ \\
\hline Running variable & $\begin{array}{c}0.0018 \\
(0.0015)\end{array}$ & $\begin{array}{c}0.0012 \\
(0.0016)\end{array}$ & $\begin{array}{c}-0.0011 \\
(0.0018)\end{array}$ & $\begin{array}{c}-0.0013 \\
(0.0019)\end{array}$ & $\begin{array}{c}0.0004 \\
(0.0008)\end{array}$ & $\begin{array}{c}0.0004 \\
(0.0008)\end{array}$ & $\begin{array}{c}-0.0011 \\
(0.0010)\end{array}$ & $\begin{array}{c}-0.0003 \\
(0.0011)\end{array}$ \\
\hline Running $\times$ Treatment & $\begin{array}{c}0.0004 \\
(0.0022)\end{array}$ & $\begin{array}{c}0.0006 \\
(0.0023)\end{array}$ & $\begin{array}{c}0.0004 \\
(0.0020)\end{array}$ & $\begin{array}{c}0.0005 \\
(0.0022)\end{array}$ & $\begin{array}{l}-0.0015 \\
(0.0012)\end{array}$ & $\begin{array}{c}-0.0012 \\
(0.0011)\end{array}$ & $\begin{array}{c}0.0007 \\
(0.0022)\end{array}$ & $\begin{array}{c}0.0001 \\
(0.0021)\end{array}$ \\
\hline Single & & $\begin{array}{c}0.0363^{* * *} \\
(0.0119)\end{array}$ & & $\begin{array}{c}0.0339^{* * *} \\
(0.0086)\end{array}$ & & $\begin{array}{c}0.0610^{* * *} \\
(0.0074)\end{array}$ & & $\begin{array}{c}-0.1311^{* * *} \\
(0.0075)\end{array}$ \\
\hline Age gap $\times$ couple & & $\begin{array}{c}0.0069^{* * *} \\
(0.0008)\end{array}$ & & $\begin{array}{c}-0.0047^{* * *} \\
(0.0010)\end{array}$ & & $\begin{array}{c}0.0013^{* *} \\
(0.0006)\end{array}$ & & $\begin{array}{c}-0.0034^{* * *} \\
(0.0011)\end{array}$ \\
\hline Children & & $\begin{array}{c}-0.0005 \\
(0.0137)\end{array}$ & & $\begin{array}{c}-0.0517^{* * *} \\
(0.0139)\end{array}$ & & $\begin{array}{l}-0.0020 \\
(0.0053)\end{array}$ & & $\begin{array}{c}0.0542^{* * *} \\
(0.0146)\end{array}$ \\
\hline High education & & $\begin{array}{c}0.1631^{* * *} \\
(0.0126)\end{array}$ & & $\begin{array}{c}-0.0612^{* * *} \\
(0.0094)\end{array}$ & & $\begin{array}{c}-0.0381^{* * *} \\
(0.0048)\end{array}$ & & $\begin{array}{c}-0.0638^{* * *} \\
(0.0083)\end{array}$ \\
\hline West & & $\begin{array}{l}0.0267^{*} \\
(0.0151)\end{array}$ & & $\begin{array}{c}-0.1148^{* * *} \\
(0.0180)\end{array}$ & & $\begin{array}{c}-0.0539^{* * *} \\
(0.0081)\end{array}$ & & $\begin{array}{c}0.1420^{* * *} \\
(0.0044)\end{array}$ \\
\hline Age 61 & & $\begin{array}{c}-0.0373^{* * *} \\
(0.0062)\end{array}$ & & $\begin{array}{c}0.0476^{* * *} \\
(0.0077)\end{array}$ & & $\begin{array}{c}-0.0080^{* *} \\
(0.0036)\end{array}$ & & $\begin{array}{l}-0.0024 \\
(0.0033)\end{array}$ \\
\hline Age 62 & & $\begin{array}{c}-0.0845^{* * *} \\
(0.0066)\end{array}$ & & $\begin{array}{c}0.1015^{* * *} \\
(0.0085)\end{array}$ & & $\begin{array}{c}-0.0144^{* * *} \\
(0.0040)\end{array}$ & & $\begin{array}{c}-0.0025 \\
(0.0060)\end{array}$ \\
\hline German & & $\begin{array}{c}0.1457^{* * *} \\
(0.0185)\end{array}$ & & $\begin{array}{c}0.0088 \\
(0.0188)\end{array}$ & & $\begin{array}{c}-0.0691^{* * *} \\
(0.0160)\end{array}$ & & $\begin{array}{c}-0.0855^{* * *} \\
(0.0185)\end{array}$ \\
\hline Constant & $\begin{array}{c}0.4299^{* * *} \\
(0.0132)\end{array}$ & $\begin{array}{c}0.2854^{* * *} \\
(0.0264)\end{array}$ & $\begin{array}{c}0.3496^{* * *} \\
(0.0132)\end{array}$ & $\begin{array}{c}0.3774^{* * *} \\
(0.0228)\end{array}$ & $\begin{array}{c}0.0629^{* * *} \\
(0.0043)\end{array}$ & $\begin{array}{c}0.1677^{* * *} \\
(0.0168)\end{array}$ & $\begin{array}{c}0.1576^{* * *} \\
(0.0076)\end{array}$ & $\begin{array}{c}0.1695^{* * *} \\
(0.0245)\end{array}$ \\
\hline X Variables & No & Yes & No & Yes & No & Yes & No & Yes \\
\hline Observations & 22,507 & 22,507 & 22,507 & 22,507 & 22,507 & 22,507 & 22,507 & 22,507 \\
\hline Pre-policy mean & .42 & .42 & .36 & .36 & .06 & .06 & .17 & .17 \\
\hline
\end{tabular}

obtained in the main specification. In addition, we provide further supporting evidence for the identification assumptions using placebo tests. More specifically, we estimate the main specification, but we impose the reform cutoff artificially to January 1951 or to January 1953. Since the pension reform affected cohorts from January 1952, we should not see any significant treatment effect in these placebo tests. The results of this exercise are displayed in Table 4. As expected, the estimated placebo effects are all insignificant and the point estimates are very close to zero 18

\subsection{Spillover effect on male labor market outcomes}

While studies document sizable spillover effects of pension reforms on female employment, the sign and the magnitude of spillover effects for male partners is less clear. As mentioned in the introduction, most studies find insignificant results. For example Lalive

${ }^{18}$ Note, that the smaller sample size in these placebo regressions is due to the age restrictions we put in order to achieve an age balanced sample. The placebo test 1951 only includes age 61 and 62 , whereas the placebo test 1953 only includes women aged 60 and 61 . 
Table 4: Placebo reforms

\begin{tabular}{|c|c|c|c|c|}
\hline & Employed & Retired & Unemployed & Inactive \\
\hline \multicolumn{5}{|l|}{ Placebo reform 1951} \\
\hline Placebo treatment 1951 & $\begin{array}{l}-0.0155 \\
(0.0143)\end{array}$ & $\begin{array}{c}0.0212 \\
(0.0158)\end{array}$ & $\begin{array}{l}-0.0032 \\
(0.0076)\end{array}$ & $\begin{array}{l}-0.0025 \\
(0.0145)\end{array}$ \\
\hline Running variable 1951 & $\begin{array}{c}0.0051^{* * *} \\
(0.0012)\end{array}$ & $\begin{array}{c}-0.0044^{* * *} \\
(0.0009)\end{array}$ & $\begin{array}{l}-0.0003 \\
(0.0008)\end{array}$ & $\begin{array}{l}-0.0004 \\
(0.0012)\end{array}$ \\
\hline Running $\times$ Treatment 1951 & $\begin{array}{l}-0.0025 \\
(0.0022)\end{array}$ & $\begin{array}{c}0.0021 \\
(0.0024)\end{array}$ & $\begin{array}{c}0.0011 \\
(0.0012)\end{array}$ & $\begin{array}{l}-0.0007 \\
(0.0018)\end{array}$ \\
\hline Observations & 14,998 & 14,998 & 14,998 & 14,998 \\
\hline \multicolumn{5}{|l|}{ Placebo reform 1953} \\
\hline Placebo treatment 1953 & $\begin{array}{c}0.0086 \\
(0.0150)\end{array}$ & $\begin{array}{l}-0.0098 \\
(0.0148)\end{array}$ & $\begin{array}{l}-0.0060 \\
(0.0064)\end{array}$ & $\begin{array}{c}0.0072 \\
(0.0170)\end{array}$ \\
\hline Running variable 1953 & $\begin{array}{c}0.0017 \\
(0.0015)\end{array}$ & $\begin{array}{l}-0.0000 \\
(0.0010)\end{array}$ & $\begin{array}{l}-0.0009 \\
(0.0007)\end{array}$ & $\begin{array}{l}-0.0008 \\
(0.0016)\end{array}$ \\
\hline Running $\times$ Treatment 1953 & $\begin{array}{c}0.0013 \\
(0.0024)\end{array}$ & $\begin{array}{l}-0.0010 \\
(0.0020)\end{array}$ & $\begin{array}{c}0.0013 \\
(0.0013)\end{array}$ & $\begin{array}{l}-0.0017 \\
(0.0024)\end{array}$ \\
\hline Observations & 14,997 & 14,997 & 14,997 & 14,997 \\
\hline \multicolumn{5}{|c|}{$\begin{array}{l}\text { Source: RDC of the Federal Statistical Office and Statistical Offices of the Länder, Mikrozen- } \\
\text { sus, 2011-2015, own calculations. } \\
\text { For the placebo tests, the cohort affected by the reform is artificially set to } 1951 \text { or 1953, } \\
\text { respectively. The placebo test } 1951 \text { only includes age groups } 61 \text { and } 62 \text { from cohorts 1950- } \\
\text { 1951. The placebo test } 1953 \text { only includes women aged } 60 \text { and } 61 \text { from cohorts } 1952-1953 . \\
\text { Robust standard errors in parentheses - clustered on month of birth. Significance levels: *: } \\
0.10,^{* *}: 0.05,{ }^{* * *}: 0.01 \text {. Unemployed }=\text { non-employed, with ALG/ALGII. Inactive }=\text { non- } \\
\text { employed, without ALG/ALGII. } \\
\text { All regressions include partnership/marital status, age gap ( } \times \text { couple), non-married children } \\
\text { in household }(0 / 1) \text {, high education }(0 / 1) \text {, west Germany, German, age fixed effects, and a } \\
\text { constant. }\end{array}$} \\
\hline
\end{tabular}

and Parrotta (2017) for Switzerland show that only women react to retirement of the partner. Similarly, Selin (2017) does not find any spillover effect on male spouses in Sweden. In contrast, Atalay and Barrett (2016) find sizable spillover effects for both men and women in Australia. The specific result for Australia is consistent with the pension rules in this country 19

To estimate potential spillover effects for men in Germany, we exploit the increase in the ERA for women. Specifically, we use the same econometric model as in the previous analysis (Equation 1), however instead of female labor market outcome we study the effect on labor market outcomes of the partner. Our estimates reject spillover effects of the pension reform. In Table 5, we show that the partners' labor market outcomes do not react significantly to the increase in the female ERA. Specifically, the point estimates suggest a small decrease in retirement and a very small increases in employment, unemployment, and inactivity. However, these effects are all insignificant.

\footnotetext{
${ }^{19}$ Pensions are non-contributory and eligibility is not tied to the prior work history. Moreover, in contrast to most other countries, pensions are means-tested on household income. This creates financial incentives for spillover effects for couples who are eligible to benefits.
} 
Table 5: Labor market status of male partner

\begin{tabular}{|c|c|c|c|c|}
\hline & Partner retired & Partner employed & Partner unemployed & Partner inactive \\
\hline Treatment & $\begin{array}{l}-0.0232 \\
(0.0195)\end{array}$ & $\begin{array}{c}0.0105 \\
(0.0113)\end{array}$ & $\begin{array}{c}0.0090 \\
(0.0067)\end{array}$ & $\begin{array}{c}0.0036 \\
(0.0098)\end{array}$ \\
\hline Running variable & $\begin{array}{c}0.0016 \\
(0.0019)\end{array}$ & $\begin{array}{l}-0.0007 \\
(0.0014)\end{array}$ & $\begin{array}{c}-0.0010^{* *} \\
(0.0004)\end{array}$ & $\begin{array}{c}0.0001 \\
(0.0012)\end{array}$ \\
\hline Running $\times$ Treatment & $\begin{array}{l}-0.0026 \\
(0.0026)\end{array}$ & $\begin{array}{l}0.0034^{*} \\
(0.0017)\end{array}$ & $\begin{array}{c}0.0008 \\
(0.0009)\end{array}$ & $\begin{array}{l}-0.0015 \\
(0.0015)\end{array}$ \\
\hline Observations & 15,841 & 15,841 & 15,841 & 15,841 \\
\hline Pre-policy mean & .551 & .341 & .036 & .073 \\
\hline
\end{tabular}

The insignificant spillover effect is important for the interpretation of the heterogeneous employment effects on the household level. Our findings imply that male employment status and male earnings are not affected by the pension reform and are exogenous. Therefore, we can stratify the sample by partners' employment and earnings in order to estimate the causal reform effect separately for women with retired and not retired partners as well as by the partners' earnings.

\subsection{Heterogeneity analysis}

The documented average labor market effects of the 1999 pension reform might disguise heterogeneous effects for specific subgroups that are central to understanding the implications of the change in the pension rules. In particular, it is important to quantify how the change in employment, unemployment, and inactivity, i.e. the substitution effects, differ between socio-demographic groups and by financial resources of the household. Therefore, we present the estimation results of Equation 1 for the female labor market outcomes by subgroups, first on the individual level (Table 6) and second on the household level (Tables 7 and 8 ).

We show, in Table 6, in addition to the average effect, heterogeneous results by the marital status and female education. We only present the treatment effects for the different outcomes and the respective pre-policy means. All specifications include additional covariates and linear time trends before and after January 1952. The results provide first evidence of important heterogeneity of the substitution effects. Overall, retirement effects are comparable; for all groups we find negative and sizable retirement effects. The effects are slightly higher for women in couples and for women without higher education, yet the pre-policy means for these groups are also higher. Thus, the reform partially 
Table 6: Heterogeneous effects by individual characteristics

\begin{tabular}{|c|c|c|c|c|c|}
\hline Sample & Main & Singles & Couples & High educ. & Not high educ. \\
\hline \multicolumn{6}{|l|}{ Retirement } \\
\hline Treatment & $\begin{array}{c}-0.1608^{* * *} \\
(0.0148)\end{array}$ & $\begin{array}{c}-0.1292^{* * *} \\
(0.0214)\end{array}$ & $\begin{array}{c}-0.1745^{* * *} \\
(0.0155)\end{array}$ & $\begin{array}{c}-0.1302^{* * *} \\
(0.0196)\end{array}$ & $\begin{array}{c}-0.1673^{* * *} \\
(0.0172)\end{array}$ \\
\hline Observations & 22,507 & 6,666 & 15,841 & 3,489 & 19,018 \\
\hline Pre-Policy Mean & .36 & .35 & .36 & .32 & .36 \\
\hline \multicolumn{6}{|l|}{ Employment } \\
\hline Treatment & $\begin{array}{c}0.0839^{* * *} \\
(0.0187)\end{array}$ & $\begin{array}{c}0.0745^{* * *} \\
(0.0243)\end{array}$ & $\begin{array}{c}0.0872^{* * *} \\
(0.0242)\end{array}$ & $\begin{array}{l}0.0951^{* *} \\
(0.0364)\end{array}$ & $\begin{array}{c}0.0827^{* * *} \\
(0.0195)\end{array}$ \\
\hline Observations & 22,507 & 6,666 & 15,841 & 3,489 & 19,018 \\
\hline Pre-Policy Mean & .42 & .47 & .4 & .55 & .39 \\
\hline \multicolumn{6}{|l|}{ Unemployment } \\
\hline Treatment & $\begin{array}{l}0.0170^{* *} \\
(0.0071)\end{array}$ & $\begin{array}{c}0.0298 \\
(0.0206)\end{array}$ & $\begin{array}{l}0.0126^{*} \\
(0.0063)\end{array}$ & $\begin{array}{c}0.0121 \\
(0.0103)\end{array}$ & $\begin{array}{l}0.0188^{* *} \\
(0.0080)\end{array}$ \\
\hline $\begin{array}{l}\text { Observations } \\
\text { Pre-Policy Mean }\end{array}$ & $\begin{array}{c}22,507 \\
.06\end{array}$ & $\begin{array}{l}6,666 \\
.1\end{array}$ & $\begin{array}{c}15,841 \\
.04\end{array}$ & $\begin{array}{c}3,489 \\
.04\end{array}$ & $\begin{array}{c}19,018 \\
.06\end{array}$ \\
\hline \multicolumn{6}{|l|}{ Inactivity } \\
\hline Treatment & $\begin{array}{c}0.0599 * * * \\
(0.0163)\end{array}$ & $\begin{array}{c}0.0249^{* *} \\
(0.0114)\end{array}$ & $\begin{array}{c}0.0747^{* * *} \\
(0.0203)\end{array}$ & $\begin{array}{c}0.0229 \\
(0.0216)\end{array}$ & $\begin{array}{c}0.0657^{* * *} \\
(0.0178)\end{array}$ \\
\hline Observations & 22,507 & 6,666 & 15,841 & 3,489 & 19,018 \\
\hline Pre-Policy Mean & .17 & .08 & .2 & .09 & .18 \\
\hline
\end{tabular}

evens out differences in retirement rates across subgroups. When considering the substitution effects into employment, unemployment, and inactivity, we find more pronounced differences between the groups. For single women, we find a large and positive employment effect of about 7.5 percentage points, which clearly exceeds the positive effect on inactivity (about 2.5 percentage points); the effect on unemployment is not significantly different from zero. In contrast, for women in couple households, all substitution effects are significant and the size of the increase in employment and inactivity is, with about 9 and 7.5 percentage points, comparable. The effect on unemployment is, with one percentage point, clearly smaller but significant. The differences by education are similar. Women with higher education compensate a large share of the negative retirement effect by an increase in employment. This is different for women with low or medium education: only about half of the reduction in retirement results in an increase in employment, the combined effect on inactivity and unemployment has, with more than 8 percentage points, the same magnitude for this group. 
The heterogeneous effects by marital status and education point at two important mechanisms that can explain heterogeneity in female labor market effects. First, the large substitution effect into inactivity among women in couples, which is significantly smaller for single women, is consistent with household income affecting substitution patterns. The results suggest that women in couple households are more likely to substitute into inactivity as they can rely on the income of their partner in the household context. Second, we find a stronger substitution effect into employment for women with higher education compared to women with lower education; to a large extent, the latter group enters inactivity or unemployment. The lower substitution effect into employment can be related to higher employment restrictions due to labor market constraints or more health demanding occupations for women without high education, or can be explained by higher preferences for leisure time. In the following, we study heterogeneous effects on the household level to learn more about these mechanisms.

In Table 7, we focus only on women in couple households. In addition to the average effects for couples (Column 1), we show the effects by the partners' retirement status and earnings. The heterogeneity of the substitution pattern for the reduction in retirement underlines the role of the safety net provided by the partner's income. Substitution effects into employment are not significant for women when the partner is not retired (Column 3) or relatively low (5 percentage points) when the partner has high income (Column 5). For these groups, the effect on inactivity dominates; inactivity increases by between 8 and 9 percentage points in these subgroups. In contrast, the employment effects are clearly dominating for women with a retired partner (12.4 percentage points) or for women with a low income partner (12.5 percentage points). Moreover, we find a relatively large and significant increase of 2.4 percentage points in unemployment for women with a low income partner. This substitution pattern suggests that, on average, women in these groups cannot or only partly rely on other income in the household and, therefore, these women increase employment.

To better understand the lower substitution effects into employment for women with high partner income or without higher education, we further differentiate the labor market effects and split the results for women with low or high income partners by female education (Table 8). We find strong employment effects for women with and without higher education when the partner income is low. This underlines again the important role of household income. However, the relative size of the employment effect differs by education. For women without higher education, we find at the same time a sizable substitution effect into unemployment and inactivity while for women with higher education and low income partners these effects are smaller and not significant. This different pat- 
Table 7: Heterogeneous effects by household characteristics

\begin{tabular}{|c|c|c|c|c|c|}
\hline Sample & Couples & Partner ret & Partner not ret & Low P.Inc & High P.Inc \\
\hline \multicolumn{6}{|l|}{ Retirement } \\
\hline Treatment & $\begin{array}{c}-0.1745^{* * *} \\
(0.0155)\end{array}$ & $\begin{array}{c}-0.1881^{* * *} \\
(0.0263)\end{array}$ & $\begin{array}{c}-0.1523^{* * *} \\
(0.0189)\end{array}$ & $\begin{array}{c}-0.2048^{* * *} \\
(0.0306)\end{array}$ & $\begin{array}{c}-0.1422^{* * *} \\
(0.0187)\end{array}$ \\
\hline Observations & 15,841 & 8,607 & 7,234 & 7,781 & 8,060 \\
\hline Pre-Policy Mean & .36 & .42 & .29 & .4 & .32 \\
\hline \multicolumn{6}{|l|}{ Employment } \\
\hline Treatment & $\begin{array}{c}0.0872^{* * *} \\
(0.0242)\end{array}$ & $\begin{array}{c}0.1235^{* * *} \\
(0.0297)\end{array}$ & $\begin{array}{c}0.0393 \\
(0.0262)\end{array}$ & $\begin{array}{c}0.1253^{* * *} \\
(0.0303)\end{array}$ & $\begin{array}{l}0.0524^{*} \\
(0.0292)\end{array}$ \\
\hline Observations & 15,841 & 8,607 & 7,234 & 7,781 & 8,060 \\
\hline Pre-Policy Mean & .4 & .34 & .47 & .39 & .4 \\
\hline \multicolumn{6}{|l|}{ Unemployment } \\
\hline Treatment & $\begin{array}{l}0.0126^{*} \\
(0.0063)\end{array}$ & $\begin{array}{l}-0.0007 \\
(0.0083)\end{array}$ & $\begin{array}{l}0.0285^{*} \\
(0.0154)\end{array}$ & $\begin{array}{c}0.0237^{* *} \\
(0.0108)\end{array}$ & $\begin{array}{c}0.0013 \\
(0.0090)\end{array}$ \\
\hline $\begin{array}{l}\text { Observations } \\
\text { Pre-Policy Mean }\end{array}$ & $\begin{array}{c}15,841 \\
.04\end{array}$ & $\begin{array}{c}8,607 \\
.04\end{array}$ & $\begin{array}{l}7,234 \\
.05\end{array}$ & $\begin{array}{c}7,781 \\
.07\end{array}$ & $\begin{array}{c}8,060 \\
.02\end{array}$ \\
\hline \multicolumn{6}{|l|}{ Inactivity } \\
\hline Treatment & $\begin{array}{c}0.0747^{* * *} \\
(0.0203)\end{array}$ & $\begin{array}{c}0.0653^{* * *} \\
(0.0224)\end{array}$ & $\begin{array}{c}0.0844^{* * *} \\
(0.0281)\end{array}$ & $\begin{array}{l}0.0558^{* *} \\
(0.0217)\end{array}$ & $\begin{array}{c}0.0885^{* * *} \\
(0.0302)\end{array}$ \\
\hline Observations & 15,841 & 8,607 & 7,234 & 7,781 & 8,060 \\
\hline Pre-Policy Mean & .2 & .2 & .2 & .14 & .26 \\
\hline $\begin{array}{l}\text { Source: RDC of th } \\
2015 \text {, own calculat } \\
\text { Robust standard } \\
0.05, * * *: 0.01 . \\
\text { Each coefficient re } \\
\text { different on each } \\
\text { high education }(0\end{array}$ & $\begin{array}{l}\text { Federal Stat } \\
\text { ns. } \\
\text { ors in parent } \\
\text { cesents a sep } \\
\text { of the disco }\end{array}$ & $\begin{array}{l}\text { cal Office an } \\
\text { es - clustere }\end{array}$ & $\begin{array}{l}\text { regressions inc } \\
\text { couple), non-ma } \\
\text { d effects, and a }\end{array}$ & $\begin{array}{l}\text { a linear tr } \\
\text { children ir } \\
\text { tant. }\end{array}$ & $\begin{array}{l}\text { rozensus, } 2011 \\
\text { s: } *: 0.10, * * \\
\text { which can b } \\
\text { ousehold }(0 / 1)\end{array}$ \\
\hline
\end{tabular}

tern reinforces the role of differential labor market opportunities and leisure preferences by education.

For highly educated women with high income partners, the results show no clear substitution pattern, the substitution effects into different labor market states are not significant, yet the point estimates suggest that these women substitute mainly into employment and inactivity. In contrast, we find a larger increase in inactivity for women with high income partners but without high education. These women face less favorable employment opportunities. At the same time, they benefit from high income at the household level, which makes substitution into inactivity affordable.

To summarize, we document sizable labor market effects of an increase in the ERA for women, which strongly differ by subgroups. Most importantly, our results show larger employment effects for women who cannot or only partly rely on other income on the household level, i.e. single women, women with a low income partner, and women with a retired partner. Further, we find lower employment effects for women without higher ed- 
Table 8: Heterogeneous effects by household characteristics II

\begin{tabular}{|c|c|c|c|c|}
\hline \multirow[t]{2}{*}{ Sample } & \multicolumn{2}{|c|}{ Low partner income (LIP) } & \multicolumn{2}{|c|}{ High partner income (HIP) } \\
\hline & LIP, no high educ. & LIP, high educ. & HIP, no high educ. & HIP, high educ. \\
\hline \multicolumn{5}{|l|}{ Retirement } \\
\hline Treatment & $\begin{array}{c}-0.2094^{* * *} \\
(0.0312)\end{array}$ & $\begin{array}{c}-0.1794^{* * *} \\
(0.0531)\end{array}$ & $\begin{array}{c}-0.1466^{* * *} \\
(0.0212)\end{array}$ & $\begin{array}{c}-0.1199^{* *} \\
(0.0556)\end{array}$ \\
\hline Observations & 6,697 & 1,084 & 6,770 & 1,290 \\
\hline \multicolumn{5}{|l|}{ Employment } \\
\hline Treatment & $\begin{array}{c}0.1208^{* * *} \\
(0.0310)\end{array}$ & $\begin{array}{c}0.1537^{* *} \\
(0.0602)\end{array}$ & $\begin{array}{l}0.0548^{*} \\
(0.0311)\end{array}$ & $\begin{array}{c}0.0517 \\
(0.0460)\end{array}$ \\
\hline Observations & 6,697 & 1,084 & 6,770 & 1,290 \\
\hline \multicolumn{5}{|c|}{ Unemployment } \\
\hline Treatment & $\begin{array}{c}0.0315^{* * *} \\
(0.0109)\end{array}$ & $\begin{array}{l}-0.0282 \\
(0.0264)\end{array}$ & $\begin{array}{l}-0.0017 \\
(0.0100)\end{array}$ & $\begin{array}{c}0.0123 \\
(0.0137)\end{array}$ \\
\hline Observations & 6,697 & 1,084 & 6,770 & 1,290 \\
\hline \multicolumn{5}{|l|}{ Inactivity } \\
\hline Treatment & $\begin{array}{c}0.0571^{* *} \\
(0.0214)\end{array}$ & $\begin{array}{c}0.0539 \\
(0.0390)\end{array}$ & $\begin{array}{c}0.0934^{* * *} \\
(0.0312)\end{array}$ & $\begin{array}{c}0.0559 \\
(0.0515)\end{array}$ \\
\hline Observations & 6,697 & 1,084 & 6,770 & 1,290 \\
\hline
\end{tabular}

ucation. As discussed above, this pattern is consistent with labor market constraints that are higher for women without higher education or potentially higher leisure preferences of these women.

\section{Results - distributional effects}

To evaluate the pension reform, it is crucial to go beyond a description of the labor market effects. It is key to understand the implication of the pension reform for the women's own and household income. Therefore, in this final section, we focus on the distributional effects of the reform.

The size and the sign of the income effects are ambiguous and depend strongly on the labor market effects: Female and household income increase with positive employment effects as labor earnings tend to be larger than pension income. In contrast, income will decrease if inactivity increases. The income effect of an increase in unemployment is small and depends on the working history. If women are eligible for insurance based unemploy- 
ment benefits (ALG I), their income in unemployment is very similar to pension income. If they receive means-tested transfers (ALG II) instead, the income in unemployment can be markedly lower.

In Tables 9, 10, and 11, we present the estimation results of Equation 1 for female income (first panel) and household income (second panel) on average and for the subgroups defined above. All regressions include linear time trends and covariates. In line with the descriptive results in Table 2 and graphical evidence (Figure A.1 in Appendix), we do not find a significant change in female and household income for the full sample. Relative to the pre-policy means, the point estimates suggest small reductions in income, about $3 \%$ for female income and about $2 \%$ for household income.

Despite the sizable heterogeneity of the labor market effects for the subgroups, we find very small differences in the income effects. For most of the subgroups, we find insignificant and rather small effects. Important exceptions are women with higher education (Column 4 in Table 9) and women with a non-retired partner (Column 4 in Table 10. For these women we find a significant negative effect on the household level. As documented above, a large share of women with non-retired partners substitutes into inactivity, which explain an income effect on the household level. We find a similar pattern for women with high income partners (Column 6 in Table 10), yet results are not significant. Women with high education have, on average, larger pension claims. This explains why this group faces large negative income effects. These negative effects are partly reduced by the positive employment effects; however, as substitution into inactivity and unemployment dominate, the group specific effect is negative.

For the policy discussion, the implication of an increase in the ERA for the incomes of the most vulnerable groups is of particular importance. Therefore, we turn to results of women without higher education with low income partners. Our results in Table 11 (Column 1) show a relatively small and not significant reduction in income for this group. This is remarkable, as for women without higher education and low partner income we find in addition to positive employment effects large substitution effects into unemployment and inactivity (see Table 8). This finding suggests that other transfer programs, such as unemployment benefits and means-tested transfers, provide an income substitution for the loss of pension income ${ }^{20}$

In Table 12, we provide empirical evidence for this hypothesis. Specifically, we show

\footnotetext{
${ }^{20}$ The micro census does not include information about the previous labor market status. Therefore, we can not identify women unemployed or inactive in the previous period and we cannot analyse the effect for this specific vulnerable group. According to Geyer and Welteke (2017) there is almost no active substitution into different employment states in response to the reform, therefore only few unemployed or inactive women make a transition into employment and can compensate for the income loss with labor earnings.
} 
estimation results of the pension reform on different transfer programs by education using Equation 1. We find a significant and sizable program substitution effect of the pension reform on the take up of means-tested transfers (ALG II).

Table 9: Heterogeneous income effects by individual characteristics

\begin{tabular}{lccccc}
\hline \multicolumn{7}{c}{ Main } & Singles & Couples & High educ. & Not high educ. \\
\hline Own income & \multicolumn{5}{c}{} \\
\hline Treatment & -31.0397 & 14.5950 & -52.8691 & -124.0881 & -14.2086 \\
& $(28.3798)$ & $(35.4162)$ & $(33.1030)$ & $(79.9688)$ & $(27.4204)$ \\
\hline Observations & 22,507 & 6,666 & 15,841 & 3,489 & 19,018 \\
Pre-policy mean & 933 & 1258 & 795 & 1348 & 855 \\
\hline Household income & \multicolumn{5}{c}{} \\
\hline Treatment & -39.8406 & 18.5347 & -50.8412 & $-239.5914^{* *}$ & -2.0217 \\
\hline \multicolumn{7}{c}{$(44.7836)$} & $(51.6606)$ & $(56.4835)$ & $(107.0604)$ & $(52.5363)$ \\
\hline $\begin{array}{l}\text { Observations } \\
\text { Pre-policy mean }\end{array}$ & 22,507 & 6,666 & 15,841 & 3,489 & 19,018 \\
\hline
\end{tabular}

Table 10: Heterogeneous income effects by household characteristics

\begin{tabular}{|c|c|c|c|c|c|}
\hline & Couples & Partner ret & Partner not ret & Low P.Inc & High P.Inc \\
\hline \multicolumn{6}{|l|}{ Own income } \\
\hline Treatment & $\begin{array}{l}-52.8691 \\
(33.1030)\end{array}$ & $\begin{array}{l}-18.8406 \\
(31.8152)\end{array}$ & $\begin{array}{l}-93.5208^{*} \\
(45.2331)\end{array}$ & $\begin{array}{l}-32.6290 \\
(34.3465)\end{array}$ & $\begin{array}{l}-70.0558 \\
(45.6428)\end{array}$ \\
\hline Observations & 15,841 & 8,607 & 7,234 & 7,781 & 8,060 \\
\hline Pre-policy mean & 795 & 768 & 828 & 807 & 783 \\
\hline \multicolumn{6}{|c|}{ Household income } \\
\hline Treatment & $\begin{array}{c}-50.8412 \\
(56.4835)\end{array}$ & $\begin{array}{c}28.2769 \\
(51.3130)\end{array}$ & $\begin{array}{c}-186.4326^{*} \\
(101.9515)\end{array}$ & $\begin{array}{l}-57.7038 \\
(41.6194)\end{array}$ & $\begin{array}{l}-88.1367 \\
(93.9426)\end{array}$ \\
\hline Observations & 15,841 & 8,607 & 7,234 & 7,781 & 8,060 \\
\hline Pre-policy mean & 2746 & 2391 & 3180 & 1989 & 3523 \\
\hline
\end{tabular}


Table 11: Heterogeneous income effects by household characteristics II

\begin{tabular}{|c|c|c|c|c|}
\hline & Low P.Inc, low educ & Low P.Inc, high educ & High P.Inc, low educ & High P.Inc, high educ \\
\hline \multicolumn{5}{|l|}{ Own income } \\
\hline Treatment & $\begin{array}{l}-19.0772 \\
(34.7809)\end{array}$ & $\begin{array}{r}-147.3819 \\
(99.7550)\end{array}$ & $\begin{array}{l}-48.1854 \\
(43.9274)\end{array}$ & $\begin{array}{l}-175.7517 \\
(164.5550)\end{array}$ \\
\hline Observations & 6,697 & 1,084 & 6,770 & 1,290 \\
\hline \multicolumn{5}{|c|}{ Household income } \\
\hline Treatment & $\begin{array}{l}-27.5690 \\
(36.9036)\end{array}$ & $\begin{array}{c}-256.4657 \\
(154.1001)\end{array}$ & $\begin{array}{c}-56.9987 \\
(110.9918)\end{array}$ & $\begin{array}{l}-293.9122 \\
(230.1878)\end{array}$ \\
\hline Observations & 6,697 & 1,084 & 6,770 & 1,290 \\
\hline
\end{tabular}

Table 12: Social benefit receipt

\begin{tabular}{|c|c|c|c|c|c|c|}
\hline & $\begin{array}{c}\text { Not high education } \\
\text { Average }\end{array}$ & Low part. inc. & High part. inc. & $\begin{array}{l}\text { High education } \\
\text { Average }\end{array}$ & Low part. inc. & High part. inc. \\
\hline \multicolumn{7}{|l|}{ ALG } \\
\hline Treatment & $\begin{array}{l}-0.0022 \\
(0.0041)\end{array}$ & $\begin{array}{l}-0.0033 \\
(0.0092)\end{array}$ & $\begin{array}{l}-0.0014 \\
(0.0094)\end{array}$ & $\begin{array}{c}0.0017 \\
(0.0104)\end{array}$ & $\begin{array}{l}-0.0217 \\
(0.0205)\end{array}$ & $\begin{array}{c}0.0147 \\
(0.0130)\end{array}$ \\
\hline Observations & 19,018 & 6,697 & 6,770 & 3,489 & 1,084 & 1,290 \\
\hline \multicolumn{7}{|l|}{ ALG II } \\
\hline Treatment & $\begin{array}{c}0.0207^{* *} \\
(0.0082)\end{array}$ & $\begin{array}{c}0.0336^{* * *} \\
(0.0100)\end{array}$ & $\begin{array}{c}0.0003 \\
(0.0014)\end{array}$ & $\begin{array}{l}-0.0041 \\
(0.0141)\end{array}$ & $\begin{array}{l}-0.0183 \\
(0.0273)\end{array}$ & $\begin{array}{l}-0.0044 \\
(0.0040)\end{array}$ \\
\hline Observations & 19,018 & 6,697 & 6,770 & 3,489 & 1,084 & 1,290 \\
\hline
\end{tabular}




\section{Conclusion}

In this paper, we use an RDD to evaluate the 1999 pension reform in Germany. Specifically, we estimate the ITT effects of a substantial 3-year increase in the ERA for women on different labor market outcomes. Using German micro census data allows us to conduct an in-depth analysis of heterogeneity patterns along individual and household characteristics. In addition, we study the distributional implications of the reform at the household level.

Our findings show that the reform led to a substantial reduction in retirement as well as increasing employment, unemployment, and inactivity rates. We further show that there is considerable heterogeneity in these effects along individual and household characteristics. Labor market opportunities and the financial situation of the partner seem to play key roles in shaping the individual responses to the pension reform. These results underline the importance of considering the household context when evaluating pension reforms. In addition, we show that there are no significant spillover effects on the partners of the affected women.

In the last part of our analysis, we show that, on average, there are no significant effects on own or household net income. Our subgroup analysis further shows that even financially vulnerable groups, such as single or low educated women, do not suffer significant negative income effects. Our findings suggest that this result is partly related to program substitution from pensions to means-tested out of work transfers. Thus the safety net provided by the German transfer system serves as a buffer against income losses for subgroups who are at particular risk of old age poverty.

Our findings about the heterogeneous employment and distributional effects on the household level extend the previous literature which has so far mainly focused on the individual level. When designing and reforming the pension system it is important to better understand the heterogeneous response pattern and how household net income across the income distribution and for specific vulnerable groups - is affected.

For a final evaluation of the pension reform future research is important. For the groups who prolong their working lives in response to the reform, the reform implies large cuts to leisure time which might reduce utility for the individuals and, therefore, the overall welfare of the society. At the same time, also non-market work, such as the provision of child care, long-term care, or social engagement, might also be crowded out by an increase in employment. 


\section{References}

Atalay, K., and G. Barrett (2016): "Pension incentives and the retirement decisions of couples," IZA Discussion Paper, 10013.

Atalay, K., and G. F. Barrett (2015): "The impact of age pension eligibility age on retirement and program dependence: Evidence from an Australian experiment," Review of Economics and Statistics, 97(1), 71-87.

Autor, D., A. R. Kostøl, and M. Mogstad (2015): "Disability benefits, consumption insurance, and household labor supply," Mimeo.

Banks, J., R. Blundell, and M. Casanova (2010): "The dynamics of retirement behavior in couples: Evidence from the UK and the US," Mimeo, UCLA.

Blau, D. M. (1998): "Labor Force Dynamics of Older Married Couples," Journal of Labor Economics, 16(3), 595-629.

Blundell, R., L. Pistaferri, and I. Saporta-Eksten (2016): "Consumption inequality and family labor supply.," American Economic Review, 106(2), 387-435.

Brinch, C. N., O. L. Vestad, and J. Zweimüller (2015): "Excess early retirement? Evidence from the Norwegian 2011 pension reform," Mimeo.

Coe, N. B., and K. Haverstick (2010): "Measuring the Spillover to Disability Insurance Due to the Rise in the Full Retirement Age," Boston College Center for Retirement Research Working Paper, 2010-21.

Cribb, J., C. Emmerson, and G. Tetlow (2016): "Signals matter? Large retirement responses to limited financial incentives," Labour Economics, 42, 203-212.

Destatis (2018): "Der Mikrozensus stellt sich vor," https://www.destatis.de/DE/ZahlenFakten/GesellschaftStaat/Bevoelkerung/Mikrozensus.html, available online, accessed in January 2018.

Deutsche Rentenversicherung (2017): "Rentenversicherung in Zeitreihen 2017," DRV-Schriften 22

Duggan, M., P. Singleton, and J. Song (2007): "Aching to retire? The rise in the full retirement age and its impact on the social security disability rolls," Journal of Public Economics, 91(7), 1327-1350. 
Engels, B., J. Geyer, and P. HaAn (2017): "Pension incentives and early retirement," Labour Economics, 47, 216-231.

$\begin{array}{cccccc}\text { FDZ } & \text { DER } & \text { Statistischen } & \text { Ämter } & \text { DES } & \text { Bundes UND } \\ \text { DER } & \text { LÄNDER } & (2017): & \text { "Informationen } & \text { zum } & \text { Mikrozensus," }\end{array}$
http://www.forschungsdatenzentrum.de/bestand/mikrozensus/index.asp, available online, accessed in January 2018.

Geyer, J., and C. Welteke (2017): "Closing Routes to Retirement: How Do People Respond?," DIW Discussion Paper, 1653.

Gustman, A. L., and T. L. Steinmeier (2000): "Retirement in Dual-Career Families: A Structural Model," Journal of Labor Economics, 18(3), 503-545.

HaAn, P., And V. Prowse (2015): "Optimal Social Assistance and Unemployment Insurance in a Life-Cycle Model of Family Labor Supply and Savings," IZA Discussion Paper, 8980.

Hanel, B., and R. T. Riphahn (2012): "The timing of retirement: New evidence from Swiss female workers," Labour Economics, 19(5), 718-728.

Hernes, E., S. Markussen, J. Piggott, and K. Røed (2016): "Pension reform and labor supply," Journal of Public Economics, 142, 39-55.

Krueger, A. B., and J.-S. Pischke (1992): "The effect of social security on labor supply: A cohort analysis of the Notch generation," Journal of Labor Economics, 10(4), 412-37.

Lalive, R., and P. Parrotta (2017): "How does pension eligibility affect labor supply in couples?," Labour Economics, 46, 177-188.

Lalive, R., and S. Staubli (2015): “How does raising women's full retirement age affect labor supply, income, and mortality?," NBER Retirement Research Center Paper, 1409.

Manoli, D. S., And A. Weber (2016): "The effects of the early retirement age on retirement decisions," NBER Working Paper, 22561.

Mastrobuoni, G. (2009): "Labor supply effects of the recent social security benefit cuts: Empirical estimates using cohort discontinuities," Journal of Public Economics, 93(11), 1224-1233. 
Michaud, P.-C., And F. Vermeulen (2011): "A collective labor supply model with complementarities in leisure: Identification and estimation by means of panel data," Labour Economics, 18(2), 159-167.

Oguzoglu, U., C. Polidano, and H. Vu (2016): "Impacts from delaying access to retirement benefits on welfare receipt and expenditure: Evidence from a natural experiment," IZA Discussion Paper, 10014.

RDC of the Federal Statistical Office and Statistical Offices of the LÄNDER (2011-2015): "Mikrozensus," 2011-2015, own calculcations.

SELin, H. (2017): "What happens to the husband's retirement decision when the wife's retirement incentives change?," International Tax and Public Finance, 24(3), 432-458.

Stancanelli, E., and A. van Soest (2012): "Retirement and Home Production: A Regression Discontinuity Approach," American Economic Review: Papers and proceedings, 102(3), 600-605.

Staubli, S., And J. ZweimÜLler (2013): "Does raising the early retirement age increase employment of older workers?," Journal of Public Economics, 108(C), 17-32.

Vestad, O. L. (2013): "Labour supply effects of early retirement provision," Labour Economics, 25, 98-109. 
A. Appendix 


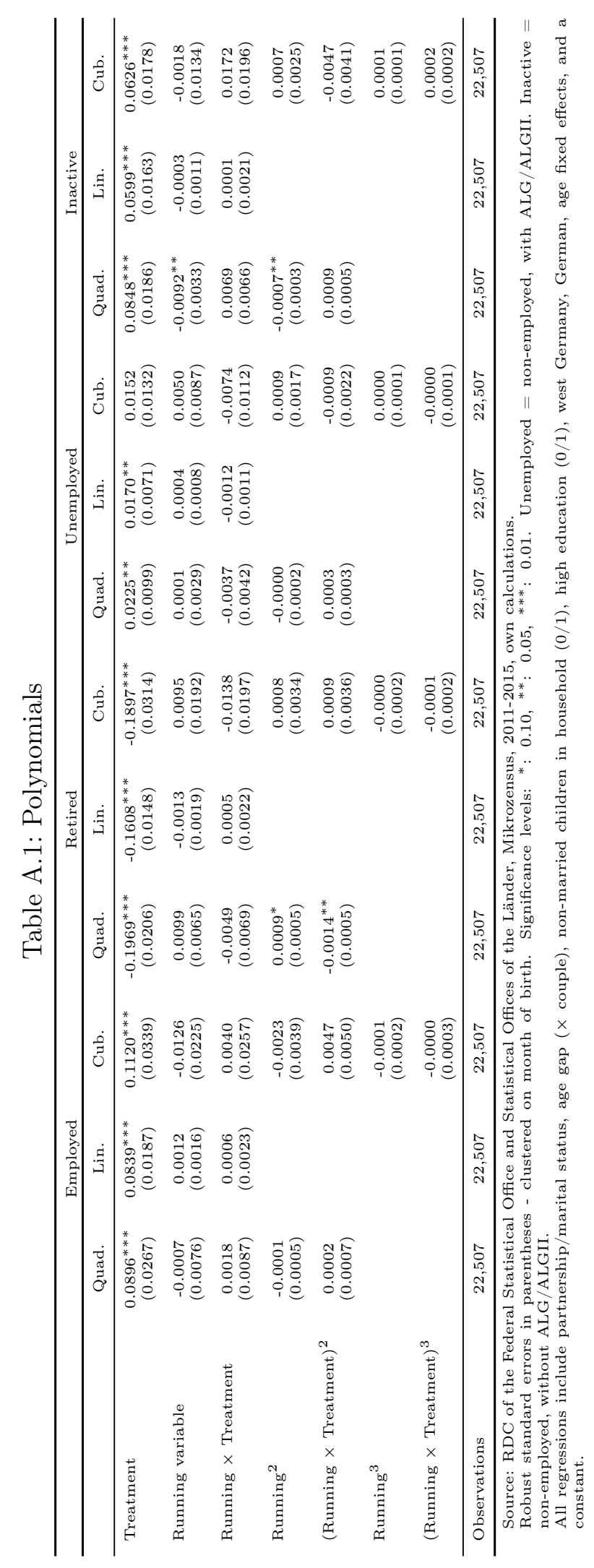


Table A.2: Treatment effects 2-year window, 61 year old women only

\begin{tabular}{lcccc}
\hline & Employed & Retired & Unemployed & Inactive \\
\hline Treatment & $0.0897^{* * *}$ & $-0.1710^{* * *}$ & $0.0171^{* *}$ & $0.0642^{* * *}$ \\
& $(0.0136)$ & $(0.0124)$ & $(0.0072)$ & $(0.0107)$ \\
Running variable & $0.0022^{* * *}$ & $-0.0017^{* *}$ & 0.0001 & -0.0005 \\
& $(0.0006)$ & $(0.0007)$ & $(0.0004)$ & $(0.0005)$ \\
Running $\times$ treatment & 0.0002 & 0.0008 & -0.0007 & -0.0004 \\
& $(0.0009)$ & $(0.0008)$ & $(0.0005)$ & $(0.0008)$ \\
\hline Observations & 14,954 & 14,954 & 14,954 & 14,954
\end{tabular}

Source: RDC of the Federal Statistical Office and Statistical Offices of the Länder, Mikrozensus, 2011-2015, own calculations.

Robust standard errors in parentheses - clustered on month of birth. Significance levels: : $0.10,{ }^{* *}: 0.05,{ }^{* * *}: 0.01$.

Each coefficient represents a separate regression. All regressions include partner-

ship/marital status, age gap ( $\times$ couple), non-married children in household $(0 / 1)$, high education $(0 / 1)$, west Germany, German, and a constant.

Figure A.1: Graphical income analysis

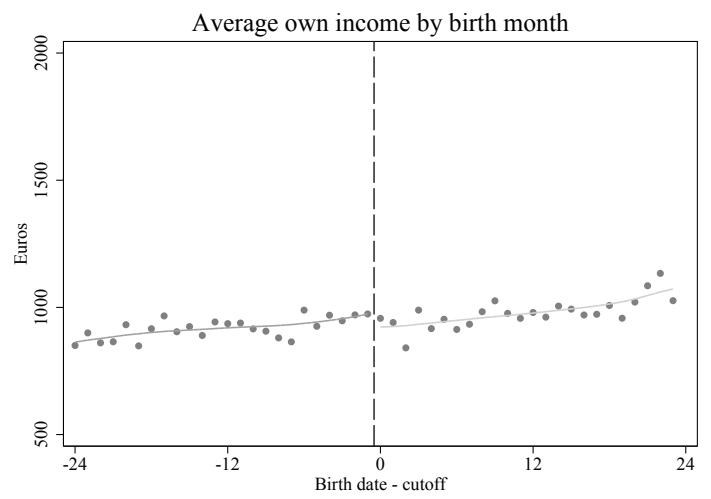

Average employment

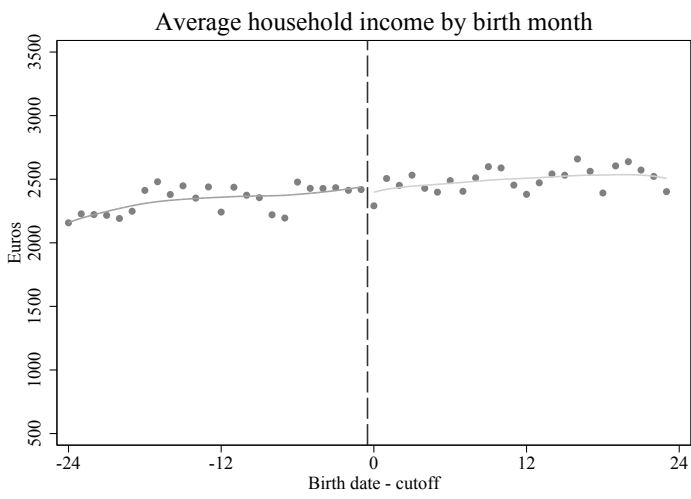

Average retirement

Source: RDC of the Federal Statistical Office and Statistical Offices of the Länder, Mikrozensus, 2011-2015, own calculations. 